\title{
Evaluation of effect of Kanchanar Guggul in Sub-clinical Hypothyroidism with respect to Agnimandya
}

\author{
Research Article
}

\section{Pooja Kombe $^{1^{*}}$, Vaishali Kuchewar ${ }^{2}$}

1. Assistant Professor, Bhausaheb Mulak Ayurved College \& Hospital, Butibori

2. Professor, Department of Kayachikitsa, Mahatma Gandhi Ayurvedic College, Salod (H)

\begin{abstract}
Sub Clinical Hypothyroidism is a condition in which there is biochemical evidence of deficiency of thyroid hormone having few or no apparent clinical features of Hypothyroidism. The prevalence of Hypothyroidism in the developed world is about 4-5\% and that of subclinical Hypothyroidism is about 415\% According to Ayurveda, the function of thermogenesis and metabolism in the body is principally related to Agni. Any deviation in the function of Agni is called as Agnimandya. It interferes with the metabolism and thermogenesis. In consideration with the role of thyroid gland in metabolism, the term Agni can be correlated. Aim and objective: this study is aimed to explore the efficacy of Kanchanar Guggul in Sub-Clinical Hypothyroidism. Methodology: this is the randomized controlled study. Total 40 patients taken in this study and divided into two groups by lottery method. Levothyroxine $25 \mathrm{mg}$ at morning and kanchanar guggul 500mg twice a day was given respectively for 30 days and follow up was taken. Conclusion: Subclinical hypothyroidism is found to be more prevalent in females in the age group of 30 to 50 years. TSH level was also decreased which indicates that it acts on metabolism process. It might be required to give Kanchanar Guggul for long duration to normalize the Agni.
\end{abstract}

Keywords: Sub Clinical Hypothyroidism, A gnimandya, Kanchnar guggul.

\section{Introduction}

Thyroid gland is located in the front of neck which produces two hormones Thyroxin [T4] and Triiodothyronine [T3]. These hormones play a major role in cell differentiation during development and help in maintaining thermogenic and metabolic homeostasis in the body.

Sub Clinical Hypothyroidism is a condition in which there is biochemical evidence of deficiency of thyroid hormone having few or no apparent clinical features of Hypothyroidism. (1)

It is defined as TSH level greater than $4.0 \mathrm{mIU} / \mathrm{L}$ (in the range of 5-10 $\mathrm{mIU} / \mathrm{L}$ ) and a normal free thyroxine level (11 to $25 \mathrm{pmol} / \mathrm{L}$ [0.9 to $1.9 \mathrm{ng} / \mathrm{dL}])$. (2)

The prevalence of Hypothyroidism in the developed world is about $4-5 \%(3)$ and that of subclinical Hypothyroidism is about $4-15 \%(4)$ India has a high prevalence of Hypothyroidism, which is about $10 \%$. It is much more common in females than males.(5)

There is no direct correlating terminology for Thyroid gland and Hypothyroidism in Ayurveda classics. According to Acharya Charak, it is not necessary to label certain disease, but it is important to understand the possible pathogenesis of the disease in

*Corresponding Author:

\section{Pooja Kombe,}

Assistant Professor,

Bhausaheb Mulak Ayurved College \& Hospital,

Butibori

Email: kombeys.pooja@gmail.com terms of Dosha, Dhatu, Mala \& Agni.(6)

However, a disease termed Galganda, characterized by neck swelling is described by Acharya Charak under Shotha Vikara. (7)

According to Ayurveda, the function of thermogenesis and metabolism in the body is principally related to Agni. It is an entity that brings about transformation. The thirteen types of Agni are responsible for all chemical reactions and transformations in the body. Any deviation in the function of Agni is called as Agnimandya. It interferes with the metabolism and thermogenesis.

In consideration with the role of thyroid gland in metabolism, the term Agni can be correlated. In the literature review of clinical features of Hypothyroidism and Agnimandya, it is found to be mostly similar. (8)

Need of the Study

+ India has a high prevalence of Hypothyroidism; which is about $10 \%$.

+ Still there is no radical cure of Hypothyroidism. Current treatment is only the replacement of the hormone.

+ According to Ayurveda, Dhatwagnimandya is the root cause of it and it is included in granthi vikar.

Kanchanar Guggul was selected, because it is indicated in granthi vikar as well as helpful to correct the Agni (with the help of its ingredients)

\section{Aim and objective}

Aim: Evaluation of efficacy of Kanchanar Guggul in Sub-Clinical Hypothyroidism. 
Objectives of the study:

- To evaluate the efficacy of Kanchanar Guggul on T3, T4 and TSH level.

- To evaluate the effect of Kanchanar Guggul on weight, BMI \& Bowel habits.

- To evaluate the effect of Kanchanar Guggul on the serum levels of total cholesterol, HDL, LDL and Triglycerides.

- To evaluate the effect of Kanchanar Guggul on Kshudha and correlate the textual clinical features of Hypothyroidism with Agnimandya and Ama.

\section{Material \& Methods}

Source of Material

Literary Source

Literature related to disease and drug was reviewed by collecting information from various books of Modern medicine, Samhita \& other classical books of Ayurveda.

\section{Clinical Source}

The Patients were selected from Kayachikitsa OPD and IPD of Mahatma Gandhi Ayurved College, Hospital \& Research Centre as well as from specialized peripheral camps.

\section{Drug Source}

- Kanchanar Guggul was procured from Dhootpapeshwar Pharmaceuticals. Single batch of Kanchanar Guggul was used for study.

- Tab. Levothyroxine $25 \mathrm{mg}$ was procured from Macleods Pharmaceuticals.

Method

Study design:-Randomized controlled study

Ethics committee approval -Before commencement of study, it was approved by Institutional ethics committee (reference no. DMIMS (DU)/IEC/2016-17/3006) on dated 11 July 2016 (Annexure - 1)

Inclusion criteria

- A patient of age group 20-50 years of either sex.

- Patients having TSH level 4 to $10 \mathrm{mIU} / \mathrm{L}$.

- Patients who are willing to participate in study.

Exclusion criteria

- Patients with MI, Stroke, Cardio Vascular surgery or major operations within 6 months prior to screening visit.

- Patients having TSH level more than $10 \mathrm{mIU} / \mathrm{L}$ or having symptoms of Myxedema.

- Patient with previous radiation treatment of the thyroid gland.

- Women who are pregnant or have a plan to become pregnant in the near future.

Withdrawal criteria

- If complicated features of hypothyroidism occurs during treatment.

- If patient is not willing to continue the treatment.

- If there are any side effects of given medicine.
Plan of study

Total 40 patients who fulfil the inclusion criteria were selected.

The patients were randomly divided [By lottery method] into two groups.

Inform consent was taken from each patient before commencement of medicine.

Group A was given standard treatment i.e. Levothyroxine $25 \mathrm{mg}$.

Group B was given Kanchanar Guggul. 30 days.

Both groups were given medicine for continuous

After completion of medicine, each patient was followed-up for next two months.

Posology

Group A - Tab. Levothyroxine $25 \mathrm{mg}$ once a day in the morning on empty stomach.

Group B - Kanchanar Guggul 500mg after breakfast between 9-10am and after dinner between 9-10pm.

Table No. 1 Assessment was done on following parameters

\begin{tabular}{|l|l|l|}
\hline $\begin{array}{l}\text { Sr. } \\
\text { No. }\end{array}$ & Parameters & Period of Assessment \\
\hline 1 & T3 \& T4 & Day 0, 30 \\
\hline 2 & TSH & Day 0, 30,60,90 \\
\hline 3 & Lipid profile & Day 0, 30 \\
\hline 4 & Weight \& BMI & Day 0, 30,60,90 \\
\hline 5 & $\begin{array}{l}\text { Bowel habits and } \\
\text { Kshudha }\end{array}$ & Day 0,30 \\
\hline
\end{tabular}

Table No. 2 Gradation of Malapravrutti (Bowel habits) and Kshudha (Appetite)

\begin{tabular}{|c|c|}
\hline Malapravrutti & Gradation \\
\hline Asamyak & 0 \\
\hline Samyak & 1 \\
\hline Kshudha & Gradation \\
\hline Asamyak & 0 \\
\hline Samyak & 1 \\
\hline
\end{tabular}

\section{Observations and Results}

This study was conducted to evaluate the effect of Kachanar Guggul in Sub-clinical Hypothyroidism with respect to Agnimandya.

Total 40 patients were participated in this study. They were randomly distributed in two groups.

Group A was Standard (Thyroxine) group and

Group B was Interventional (Kanchanar Guggul) group.

The data was coded and entered into Microsoft Excel Worksheet. Statistical analysis was done by using descriptive and inferential statistics using chi square test, student's paired and unpaired t test and software used in the analysis were SPSS 22.0 version and Graph Pad Prism 6.0 version and $p<0.05$ is considered as level of significance

Total 40 patients of age group between 20 to 50 years are selected in study (20 in each group). Out of that group A and group B, $85 \%$ and $90 \%$ patients were found respectively in the age group of 31 to 50 years.

Gender wise distribution showed that in group A 
Pooja Kombe et.al., Effect of Kanchanar Guggul in Sub-clinical Hypothyroidism with respect to Agnimandya

\begin{tabular}{|c|c|c|c|c|}
\hline \multicolumn{5}{|c|}{ Table No. 3 Correlation of Hypothyroidism with Aam \& involvement of Dosha \& Dhatvagni. } \\
\hline $\begin{array}{l}\text { Sr. } \\
\text { No. }\end{array}$ & Features of Hypothyroidism & Features of $A m a$ & Dosha involvement & $\begin{array}{l}\text { Dhatvagni } \\
\text { involvement }\end{array}$ \\
\hline 1 & $\begin{array}{l}\text { Weight gain with poor } \\
\text { appetite }\end{array}$ & Gaurav, Aruchi, Apakti & Kaphavruddhi & Rasa, Meda \\
\hline 2 & Cool peripheral extremities & Gaurav & Kaphavruddhi & Rasa,Rakta \\
\hline 3 & $\begin{array}{l}\text { Puffy face, hands, and feet } \\
\text { (myxedema), Peripheral } \\
\text { edema }\end{array}$ & Gaurav & KaphavrutVata & Rasa \\
\hline 4 & Weakness & $\begin{array}{l}\text { Balabhramsha, Alasya, } \\
\text { Klama }\end{array}$ & Kaphavruddhi & Rasa, Rakta \\
\hline 5 & Constipation & Malasanga, Anil mudhata & $\begin{array}{l}\text { Kaphavruddhi, } \\
\text { Vatasanga }\end{array}$ & Rasa \\
\hline 6 & Paraesthesia & Anilmudhata & KaphavrutVata & Rasa \\
\hline 7 & $\begin{array}{l}\text { Difficulty concentrating and } \\
\text { poor memory }\end{array}$ & Anilmudhata & KaphavrutVata & Majja \\
\hline
\end{tabular}

and group B 100\% and 90\% patients were female respectively.

Comparison of Bodyweight in group A with baseline - In group A, mean body weight was $57.65 \mathrm{~kg}$ on day 0 . It was 57.05 on $30^{\text {th }}$ day. It was slightly decreased after completion of treatment with Tablet Thyroxine. On $60^{\text {th }} \& 90^{\text {th }}$ day, it was 57.10 and 57.15 respectively.

Comparison of Body weight in group B with baseline - In group B, mean body weight was 59.50 on day 0 . It was 57.80 on $30^{\text {th }}$ day. It was significantly decreased after completion of treatment with Kanchanar Guggul. On $60^{\text {th }} \& 90^{\text {th }}$ day, it was 57.50 and 57.55 respectively.

Comparison of weight in group $\mathbf{A}$ and $\mathbf{B}$ - In the comparison of body weight in Group A \& B. Significant weight reduction was found in group B.

Graph No. 1: Comparison of weight in group A and B

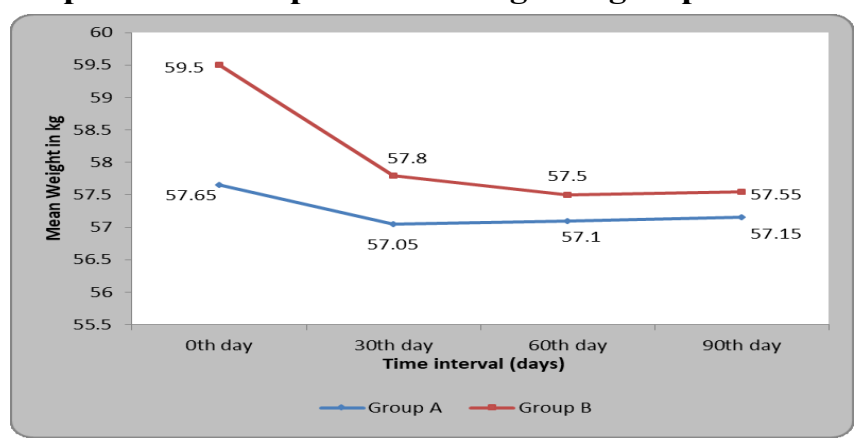

Comparison of BMI in group A with baseline - In group A, BMI was 24.49 and 24.24 on day 0 and 30 respectively. It was 24.26 and 24.28 on $60^{\text {th }}$ and $90^{\text {th }}$ day respectively.

Comparison of BMI in group B with baseline - In group B, BMI was 24.49 and 24.24 on day 0 and 30 respectively. It was 24.26 and 24.28 on $60^{\text {th }}$ and $90^{\text {th }}$ day respectively.

Comparison of BMI in group $\mathbf{A}$ and $\mathbf{B}$ - In the comparison of BMI in both the groups, BMI was decreased significantly in group B than group A.
Graph No. 2: Comparison of BMI in group A and B

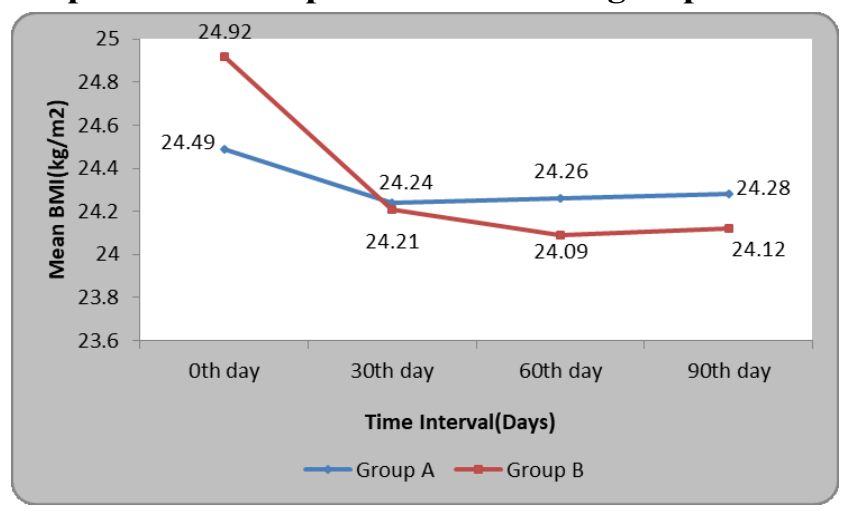

Comparison of TSH in group A with baseline - In group A, mean TSH level was 7.43 on day 0 . It was 4.79 on $30^{\text {th }}$ day i.e. after completion of medication (Thyroxine). It was 4.50 and 4.83 on $60^{\text {th }}$ and $90^{\text {th }}$ day of follow-up.

Comparison of TSH in group $\mathbf{B}$ with baseline - In group $\mathrm{B}$, The mean TSH level was 7.50 on day 0 . It was 5.52 on $30^{\text {th }}$ day i.e. after completion of medication (Kanchanar Guggul). It was 5.42 and 5.71 on $60^{\text {th }}$ and $90^{\text {th }}$ day of follow-up.

Comparison of TSH in group $\mathbf{A}$ and $\mathbf{B}$ - In the comparison of mean TSH in both the groups, it was decreased significantly in group A than group B.

\section{Graph No. 3: Comparison of TSH in group A and B}

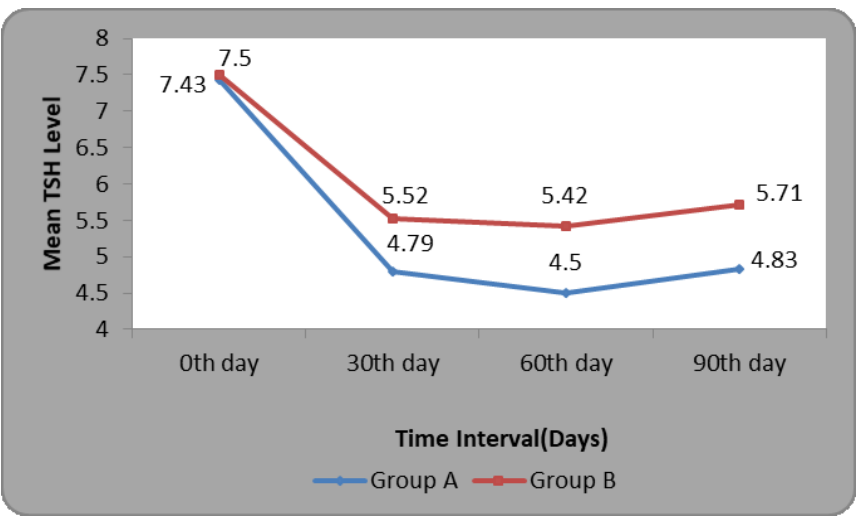


Comparison of T3 Level in group A and B with baseline - In group A, mean T3 level was 79.65 and 84.00 on 0 day and $30^{\text {th }}$ day respectively. In group B, mean T3 level was 87.80 and 93.55 on 0 day and $30^{\text {th }}$ day respectively. It is observed that the mean T3 level was increased significantly in group B.

\section{Graph No. 4: Comparison of T3 Level in group A} and $B$ with baseline

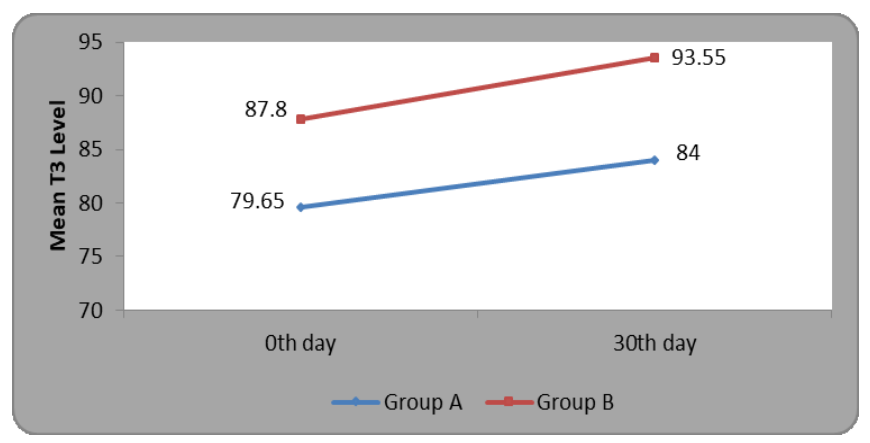

Comparison of T4 Level in group $A$ and $B$ with baseline - In group A, mean T4 level was 6.72 and 7.13 on 0 day and $30^{\text {th }}$ day respectively. In group $\mathrm{B}$, it was 6.62 and 6.95 on 0 day and $30^{\text {th }}$ day respectively. It is observed that the mean T4 level was increased significantly in group A.

\section{Graph No. 5: Comparison of T4 Level in group A} and $B$ with baseline

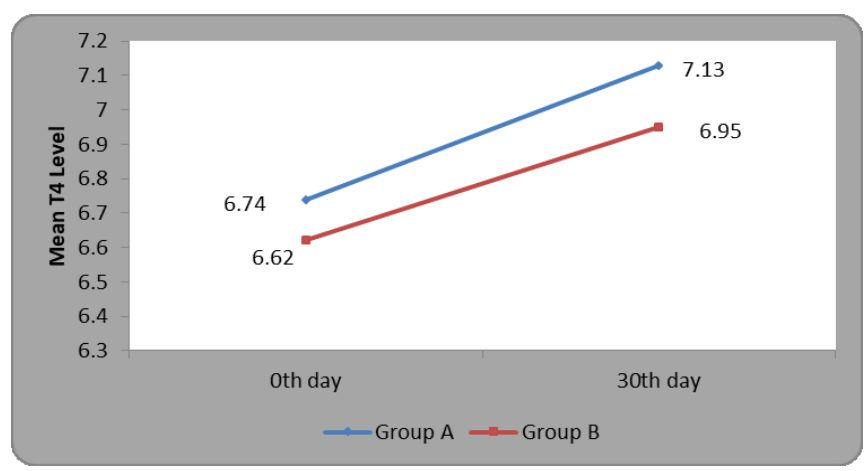

Comparison of TC Level in group $A$ and $B$ with baseline - In group A, mean TC level was 147 and 145.25 on day 0 and on $30^{\text {th }}$ day respectively. In group $\mathrm{B}$, mean TC level was 157.60 and 148.00 on 0 day and $30^{\text {th }}$ day respectively. It is observed that the mean TC level was decreased significantly in group B.

Graph No. 6: Comparison of TC Level in group A and $B$ with baseline

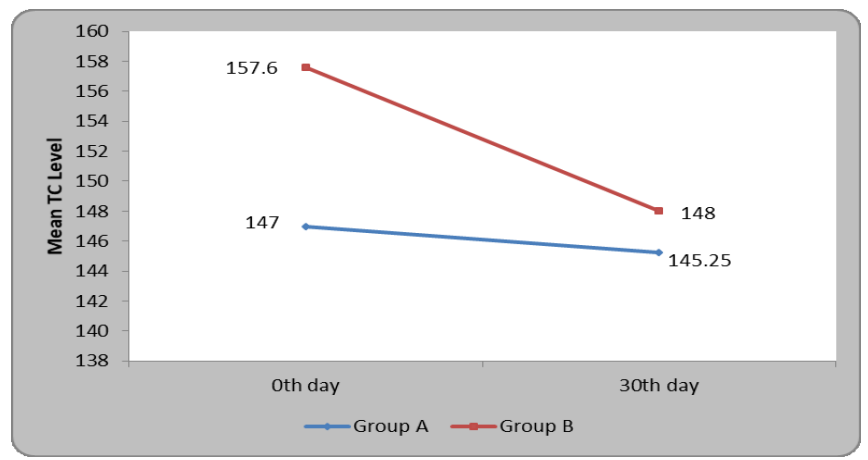

Comparison of HDL Level in group $A$ and $B$ with baseline -In group A, mean HDL level was 40 and44.90 on 0 day and $30^{\text {th }}$ day respectively. In group $B$, mean HDL level was 37.75 and 47.45 on 0 day and $30^{\text {th }}$ day respectively. It is observed that the mean HDL level was increased significantly in both groups.

\section{Graph No. 7: Comparison of HDL Level in group A and $B$ with baseline}

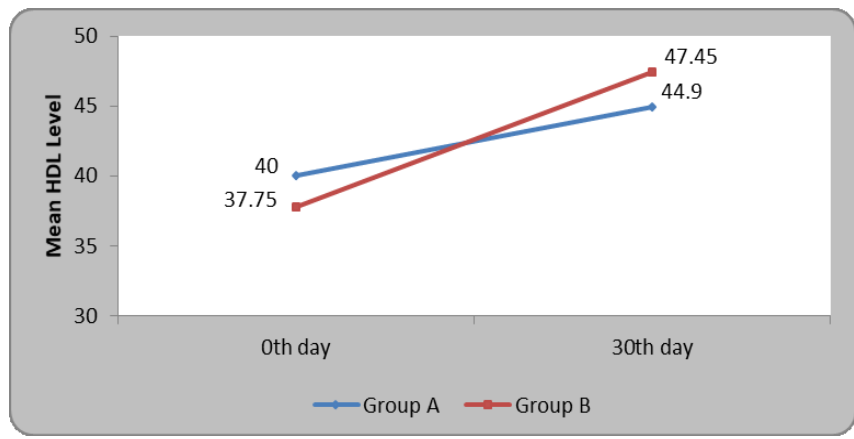

Comparison of LDL Level in group $A$ and $B$ with baseline - In group A, mean LDL level was 88.85 and 92.80 on 0 day and $30^{\text {th }}$ day respectively. In group $\mathrm{B}$, mean LDL level was 96.10 and 96 on 0 day and $30^{\text {th }}$ day respectively.

\section{Graph No. 8: Comparison of LDL Level in group A and $B$ with baseline}

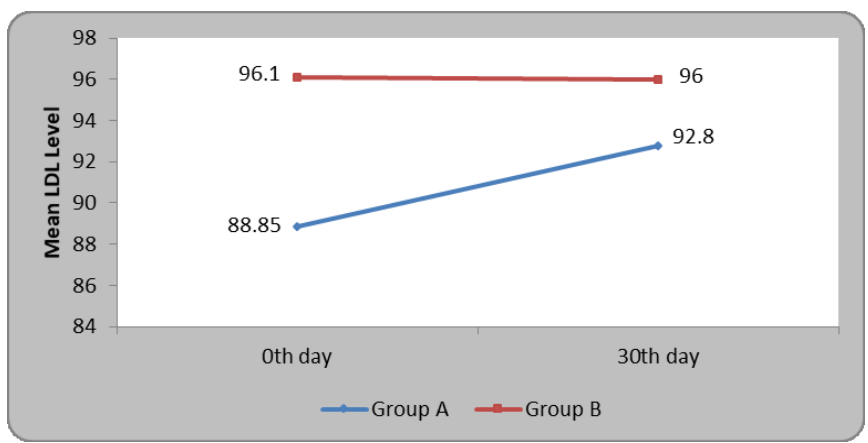

Comparison of TG Level in group A and B with baseline - Comparison of triglyceride showed that the mean Triglyceride level in group A was 112.20 and 110.05 on 0 day and $30^{\text {th }}$ day respectively. In group B, it was 123.55 and 122.55 on 0 day and $30^{\text {th }}$ day respectively. There was no significant difference in Triglycerides in both the groups.

Graph No. 9: Comparison of TG Level in group A and $B$ with baseline

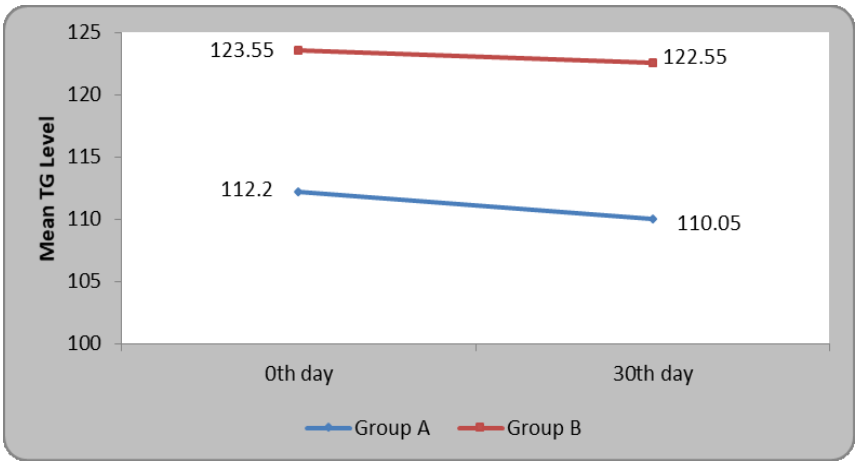


Comparison of irregularity of Bowel habit in group A and B - On 0 day, $70 \%$ and $85 \%$ patients of group A \& $\mathrm{B}$ respectively were having irregular bowel habits. On $30^{\text {th }}$ day, $35 \%$ and $5 \%$ patients of group $A \& B$ respectively were having irregular bowel habits. There was significant difference in bowel habits in group B.

\section{Graph No. 10: Comparison of irregularity of Bowel habit in group $A$ and $B$}

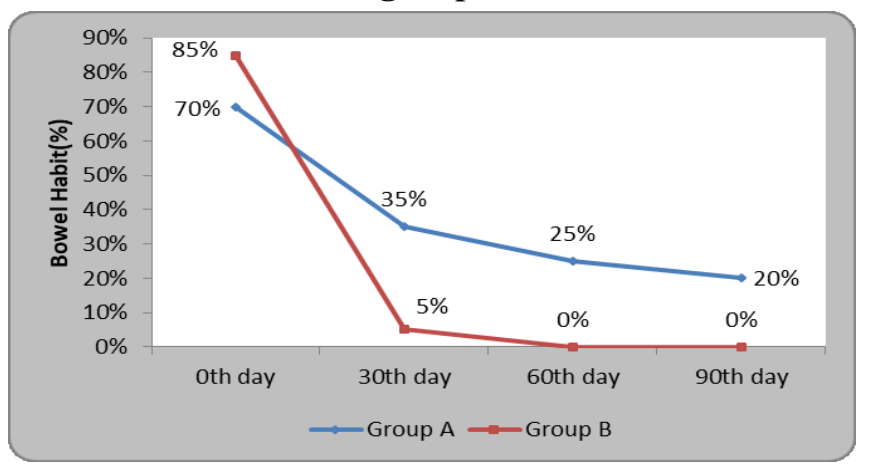

Comparison of Alpa Kshudha in group A and B - On 0 day, $60 \%$ and $65 \%$ patients of group A \& B respectively were having Alpa Kshudha. On $90^{\text {th }}$ day, $100 \%$ patients of group A \& B were having Samyak kshudha.

\section{Graph No. 11: Comparison of Alpa Kshudha in group $A$ and $B$}

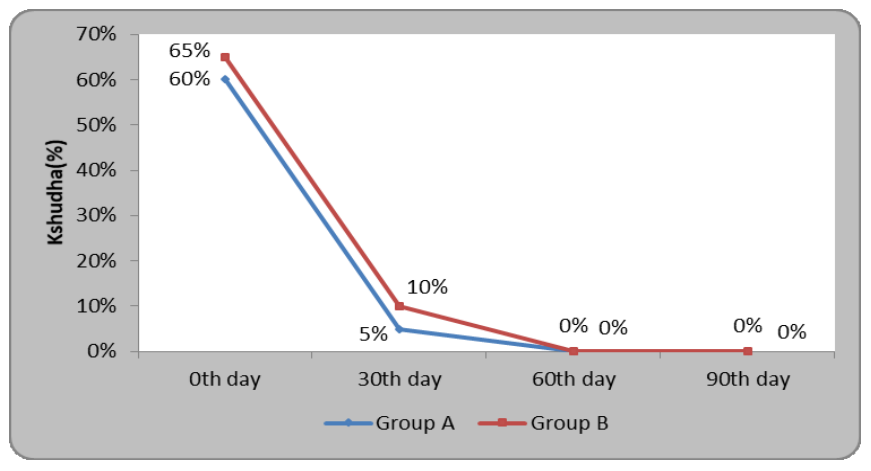

\section{Discussion}

Total 42 patients were registered; out of these, 40 patients have completed the treatment.

Group A was treated with tablet Thyroxine i.e. standard drug and group B was treated with Kanchanar Guggul. Total duration of treatment was 30 days and next 60 days was the follow-up period.

Patients were found in the age group of 30 to 50 years in both the groups. This indicates that the prevalence of Subclinical Hypothyroidism is increasing in young age group also. Out of 40 patients, 38 were females. In two population-based studies, the prevalence of subclinical hypothyroidism ranged between $7.5-8.5 \%$ in women and $4.4 \%$ in men. $(9,10)$ It is prevalent in women with increasing age. $(11,12)$

In both groups, body weight was decreased, but it was significantly decreased in group B. It might be due to the Deepan, Pachan and Lekhan properties of the drugs used in Kanchanar Guggul.

In the comparison of BMI in both the groups, it was decreased significantly in group B than group A.

On 30 days treatment, TSH level was significantly decreased in group A. It might be due to directly provided hormone Thyroxine. It was decreased up to the nearest of the normal level in group B (Kanchanar Guggul). The ingredients of it act on Agni. So it might take time to correct $A$ gni.

There was significant increase in T3 level in group B in comparison with group A.

It was observed that the mean TC level was decreased significantly in group B, Mean HDL level was increased significantly in both groups and there was no significant difference in Triglycerides in both the groups.

In Mala Pravrutti and Kshudha also, group B was having significant positive results than group A.

\section{Probable mode of action of Kanchanar Guggul}

According to Ayurveda, the root cause of Hypothyroidism is Agnimandya. So the drugs having Deepana, Pachana (Digestives), Lekhan, Strotoshodhan, Anulomana and Kaphashamaka properties are likely to check the basic pathogenesis of Hypothyroidism i.e. hypometabolism. The ingredients of Kanchanar Guggul are having above said properties.

Kanchnara(Bauhinia variegata Linn.) is a drug of choice for Granthi vikara and Galaganda.The study conducted by Veena, K. et al.Water-soluble fraction of total alcoholic extract of Bauhinia variegata Linn. at a dose of $2 \mathrm{~g} / \mathrm{kg}$ was fed to Neomercazole (150 mg/kg)induced hypothyroidic rats $(n=12$ in each group) for 20 days. The experiment resulted in enhanced thyroid function as evidenced by increased thyroidal weight ( $\mathrm{p}$ $<0.001)$, I131 uptake and decreased serum cholesterol ( $\mathrm{p}<0.05$ for both), and active thyroidal histology. (13)

The study conducted by Ghaisas MM et.al. Ethanolic extract bark of B. Variegata showed immunomodulatory activity on the primary and secondary antibody responses by humoral antibody response. It also showed phagocytic activity. (14)

Guggul is having Dipana, Pachana, and Lekhana properties. It alleviates both Vata and Kapha and regulates the Agni. The research data suggests that Guggul corrects structure and function of the thyroid significantly after melatonin induced hypothyroidism and directly stimulates thyroid function probably through some enzymatic mechanisms. (15) In another study, an investigation was made to find out the importance of Guggul in thyroid function of mice. No marked change in the concentrations of serum thyroxine $\left(\mathrm{T}_{4}\right)$ was observed, triiodothyronine $\left(\mathrm{T}_{3}\right)$ concentration and $\mathrm{T}_{3} \mathrm{~T}_{4}$ ratio were enhanced following the administration of Guggul extract . (16)

K.P. Khalsa wrote that it seems to be the case that both iodine deficiency and excess iodine can cause Hypothyroidism. He noted that the United States and Japan have the highest rates of Hashimoto's thyroiditis, as well as the highest rates of iodine intake.(17) His viewpoint is validated by the study conducted by Noel R. et al. In this study, an increase of iodine intake by 
mice through water was directly linked to the development of autoimmune thyroiditis (Hashimoto's). (18) so he suggested that the presence of iodine increases the autoantigenic potency of thyroglobulin, a major pathogenic antigen in the induction of autoimmune thyroiditis so Instead of iodine, immune enhancing, anti-inflammatory herbs should be recommended in Hypothyroidism .

Trikatu- Trikatu is predominantly having Ușhṇa, Tikṣna, Laghu, Ruksaguṇa, Katurasa, Katu vipaka \& Ușhna virya. Hence it is Kapha-vatashamaka, Deepana, Pachana, Strotovishodhana \& Shothahara properties. (19) It is effective in correcting the dysfunction of $A g n i$ seen in hypothyroidism.

Triphala - It is one of the most popular herbal remedies which 'cleanse' by promoting bowel movement. It is having Deepana, Pachana, Vatanulomaka and Strotoshodhaka properties. Hence Triphala may correct the state of Agnimandya.Various researches have demonstrated that Triphala stimulates bile secretion, helps digestion and significantly reduces serum lipid levels. (20)

So all the medicines of Kanchanar Guggul might be helpful to improve Agni through which the thyroid function is regularized.

\section{Limitations -}

This study was not conducted on Hypothyroidism; it was conducted on Sub clinical Hypothyroidism to avoid any complications. limitation.

The sample size was small because of time

\section{Recommendations}

This study can be continued on large sample size to confirm the result.

Further study can be conducted to check the effect of Kanchanar Guggul on Thyroid Peroxidase Antibody (TPO).

This study can be continued to check its effect using long duration of treatment (up to 3 months).

\section{Conclusion}

This study was conducted to analyze the effect of Kanchanar Guggul in the management of sub clinical hypothyroidism. From the observations, it can be concluded that

Hypothyroidism can be correlated with Agnimandya because of similarities in clinical features.

Subclinical hypothyroidism is found to be more prevalent in females in the age group of 30 to 50 years

It is evident that Kanchanar Guggul acts on $A g n i$ because there was significant decrease in BMI.

TSH level was also decreased which indicates that it acts on metabolism process. It might be required to give Kanchanar Guggul for long duration to normalize the Agni.

Kanchanar Guggul was also found to be helpful in regulating appetite $\&$ bowel habits.

\section{References}

1. Longo, Fauci, Kasper, Hauser, Jameson, Loscalzo, Harrison's principles of internal medicine, volume 2, 2012, the Mcgraw Hill Companies, Inc, United states of America 1976. P.2921

2. Gharib H, Tuttle RM, Baskin HJ, Fish LH, Singer PA, McDermott MT. Subclinical thyroid dysfunction: a joint statement on management from the American Association of Clinical Endocrinologists, the American Thyroid Association, and the Endocrine Society. Thyroid 2005;15(1):24-28

3. Hollowell JG, Staehling NW, Flanders WD, Hannon WH, Gunter EW, Spencer CA, et al. Serum TSH, T (4), and thyroid antibodies in the United States population (1988 to 1994): National Health and Nutrition Examination Survey (NHANES III) J ClinEndocrinol Metab., 2002; 87: 489-99.

4. Bemben DA, Hamm RM, Morgan L, Winn P, Davis A, Barton E. Thyroid disease in the elderly. Part 2.Predictability of subclinical hypothyroidism. J FamPract., 1994; 38:583-8

5. Unnikrishnan Ambika Gopalakrishnan, Kalra Sanjay, Sahay Rakesh Kumar, Bantwal Ganapathi, John Mathew, Tewari Neeraj. Prevalence of hypothyroidism in adults: An epidemiological study in eight cities of India. Indian J Endocrinol Metab., 2013 Jul-Aug; 17(4): 647-652

6. Shastri K, Chaturvedi G, editors, Charak Samhita of Agnivesha, Revised by Charak and Dridhabala, Part I, Sutra Sthana, chapter 18, Verse 44-46, Varanasi: Chaukhamba Bharati Academy, Reprint, 2004;P-383

7. Shukla V and Tripathi R, Editors, Charak Samhita, vol. 2, Chikitsasthana, Chapter 12, Verse 79 , Delhi: Choukhambha Sanskrit Pratisthan, reprint edition 2012; p-284.

8. S. Chandra et al, Conceptual study of hypothyroidism and Agnimandya, International General of Ayurvedic and Herbal medicine5:4(2015) 1932-1931

9. Wilson JMG, Junger G. Principles and practice of screening for disease. Geneva: World Health Organization; 1968.

10. Spencer CA, LoPresti JS, Patel A, et al. Applications of new chemiluminometericthyrotropin assay to subnormal measurement. J ClinEndocrinolMetab. 1990;70:453-460.

11. Ayala AR, Wartofsky L. Minimally symptomatic (subclinical) hypothyroidism. Endocrinologist. 1997;7:44-50.

12. Canaris GJ, Manowitz NR, Mayor G, et al. The Colorado thyroid disease prevalence study. Arch Intern Med. 2000;160:526-534.

13. Veena, K. et al., Effect of indigenous drugs on experimentally produced goiter, J. Res. Ind. Med., 
10, 19, 1975

14. Ghaisas MM, Shaikh SA, Deshpande AD. Evaluation of the immunomodulatory activity of ethanolic extract of the stem bark of Bauhinia variegata Linn.Int J Green Pharm 2009;3:70-4.

15. Tripathi, AK Singh SN, and GC Prasad. "Response of ComimiphoraMukul (Guggulu) on melatonin induced hypothyroidism." Ancient Science of Life Oct; 3(2) (1983): 85-90.

16. Panda, Sunanda, and AnandKar. "Gugulu (Commiphoramukul) induces triiodothyronine production: possible involvement of lipid peroxidation." Life sciences 65.12 (1999): PL137PL141.
17. Karta Purkh Singh Khalsa, C.D.-N., A.H.G. "Hashimoto's Disease and Hypothyroidism," InternationalIntegrative.com

18. Noel R. Rose, Linda Rasooly, Ali M. Saboori, and C. Lynne Burek "Linking iodine with autoimmune thyroiditis," 749-752.

19. Srivastava S, edited Sharangadhar Samhita of Acharya Sharangdhar, Madhyama Khand, Chapter 6, Verse 12, Varanasi: Chaukhamba Orientalia, Reprint., 2009; P-175.

20. https://www.planetherbs.com/specific-herbs/thewonders-of-triphala.html. 